\title{
Rezygnacja papieża z urzędu ${ }^{1}$
}

Rezygnacja Benedykta XVI z urzędu Biskupa Rzymskiego ogłoszona 11 lutego 2013 roku była dla wielu olbrzymim zaskoczeniem, bowiem w historii Kościoła takich decyzji było niewiele, a od ostatniej upłynęło ponad sześć wieków. Dla kanonistów jednak akt ten jest wprawdzie nowością tylko de facto, ale już nie de iure, gdyż przepis o rezygnacji papieża z urzędu istnieje w kanonicznym porządku prawnym od 1299 roku.

Rezygnacja - zwana także abdykacją lub dymisją - polega na dobrowolnym zrzeczeniu się przez papieża urzędu Biskupa Rzymu, co w konsekwencji powoduje utratę pełnionej przezeń najwyższej władzy w Kościele. Ze względu na szczególny charakter misji następcy św. Piotra, do papieża tylko w ograniczonym stopniu stosują się ogólnie obowiązujące przepisy w przedmiocie utraty urzędu kościelnego ${ }^{2}$, w szczególności regulujące okoliczności rezygnacji ${ }^{3}$.

I Artykuł jest rozszerzoną i uzupełnioną o okoliczności rezygnacji Benedykta XVI wersją opracowanego przez autora hasła Renuncia del Romano Pontifice, [w:] Diccionario General de Derecho Canónico, red. J. Otaduy, A. Viana, J. Sedano, t. 6, Pamplona 2012, s. 930-933.

2 Zob. J. I. Arrieta, Diritto dell'organizzazione ecclesiastica, Milano 1997, s. 232; G. Bier, Komentarz do kan. 332, [w:] Münsterischer Kommentar zum Codex Iuris Canonici, t. 2, Essen 2008, nr 10.

3 Zob. kan. 187-189 KPK. 
Nie ma też zastosowania odrębna regulacja dotycząca rezygnacji z urzędu biskupa diecezjalnego ${ }^{4}$.

Zwykłą przyczyną wakatu Stolicy Apostolskiej jest śmierć papieża (do wywołania skutków prawnych fakt ten musi zostać oficjalnie stwierdzony, zgodnie ze stosownymi przepisami ${ }^{5}$ ), która ze względu na swą oczywistość nie jest uwzględniana w Kodeksie prawa kanonicznego. Natomiast rezygnacja papieża z urzędu, uznawana za „nadzwyczajny” sposób zwolnienia urzędu Biskupa Rzymu, jest już explicite wspomniana w kan. $332 \$ 2$ KPK. Autorzy rozważają także inne hipotetyczne przyczyny utraty przez papieża swego urzędu, jak np. nieuleczalna i trwała ciężka choroba psychiczna, w następstwie której doszłoby do nieodwracalnej utraty przezeń używania rozumu (taką sytuację zrównuje się ze śmiercią papieża) czy popadnięcie przez Biskupa Rzymu w notoryjną herezję, apostazję lub schizmę (niektórzy z racji eklezjologicznych w ogóle nie dopuszczają takiej możliwości, inni przyrównują ją do dobrowolnej rezygnacji papieża $)^{6}$. Nie ma jednak żadnych przepisów prawa, które pozwalałyby na utworzenie odpowiedniej normy postępowania w takich osobliwych sytuacjach ${ }^{7}$.

4 Zob. kan. 401 KPK.

5 Zob. Ioannes Paulus II, Constitutio Apostolica Universi Dominici gregis de Sede Apostolica vacante deque Romani Pontificis electione, 22 II 1996, nr 17, AAS, R. 88, 1996, s. 305-343 [dalej: UDG]; Officium de Liturgicis Celebrationibus Summi Pontificis, Ordo Exsequiarum Romani Pontificis, Romae 2000, s. 12-13, 18-29, nr 7, 20-28.

6 Zob. F. X. Wernz, P. Vidal, Ius canonicum, t. 2: De personis, Romae 1928, s. 437440; J. Manzanares, Il Romano Pontefice e la collegialità dei vescovi, [w:] Il Codice del Vaticano II. Collegialità e primato. La suprema autorità della Chiesa, Bologna 1993, s. 60.

7 Niektórzy kanoniści mimo to wskazują, iż gdyby doszło do takiej sytuacji, kardynałowie musieliby stwierdzić sam fakt choroby psychicznej, względnie notoryjnej apostazji, herezji lub schizmy (ten ostatni przypadek trudno rozważać nawet czysto teoretycznie, skoro schizma, w myśl kan. 751, jest odmową uznania zwierzchnictwa Biskupa Rzymskiego lub utrzymywania wspólnoty z wiernymi uznającymi to zwierzchnictwo!), po czym przejść do wyboru nowego papieża. Zob. A. Montan, Il diritto nella vita e nella missione della Chiesa, t. 1: Introduzione. Norme generali. Il popolo di Dio (Libri I e II del Codice), Bologna 2000, s. 354. Nie wydaje się jednak, by taki sposób postępowania mógł być bezkonfliktowo wcielony w życie, przy braku wyraźnych przepisów, pomijając już same trudności natury teologicznej dotyczące twierdzenia o możliwości popadnięcia papieża w herezję czy apostazję. Natomiast kwestią, którą należy rozważać nie tylko czysto teoretycznie, jest hipoteza choroby psychicznej papieża. Niektórzy autorzy uznają ją za samoistną przyczynę utraty urzędu przez Biskupa Rzymu, inni zaś jedynie za przeszkodę w działaniu Stolicy Świętej. 
Artykuł 77 konstytucji apostolskiej Jana Pawła II Universi Dominici gregis stanowi, iż wszystkie przepisy dotyczące sposobu postępowania po śmierci papieża mają być zachowane w całości także w przypadku, gdyby wakat Stolicy Apostolskiej nastąpił wskutek zrzeczenia się Biskupa Rzymskiego z urzędu. Warto podkreślić, że choć przepis ten nie był nowością ${ }^{8}$, bo identyczne ogólne odesłanie zawierał też art. 78 konstytucji apostolskiej Pawła VI Romano Pontifici eligendo z 1 października 1975 roku $^{9}$, to dopiero w ustawodawstwie Jana Pawła II o wyborze papieża uległo zmianie brzmienie kilku artykułów, które przedtem odnosiły się tylko do śmierci papieża - w obowiązującej ustawie zamiast o śmierci papieża mowa jest o wakacie Stolicy Apostolskiej ${ }^{10}$.

\section{Precedensy historyczne}

W historii miało miejsce kilka przypadków przerwania pontyfikatu przed śmiercią papieża ${ }^{11}$. Nie wszystkie one są jednak należycie udokumentowane,

W tej drugiej sytuacji kan. $335 \mathrm{KPK}$ odsyła do ustaw specjalnych wydanych na tego rodzaju okoliczności, jednakże ustawy takie nie zostały do dziś ogłoszone. Autorzy odsyłają zatem, servatis de iure servandis, do przepisów odnoszących się do wakatu Stolicy Apostolskiej, przynajmniej gdy chodzi o sposób funkcjonowania dykasterii Kurii Rzymskiej. Zob. Z. Grocholewski, Canoni riguardanti il Papa e il Concilio Ecumenico nel nuovo Codice di Diritto Canonico, „Apollinaris”, R. 53, 1990, s. 596; J. Manzanares, Il Romano Pontefice..., dz. cyt., s. 61; E. Molano, Komentarz do kan. 335, [w:] Comentario exegético al Código de Derecho Canónico, red. A. Marzoa, J. Miras, R. Rodríguez-Ocańa, t. 2, Pamplona 1996, s. 585-586; J. L. Gutiérrez, Komentarz do kan. 335, [w:] Kodeks Prawa Kanonicznego. Komentarz, red. P. Majer, Kraków 2011, s. 307.

8 Po promulgowaniu konstytucji Universi Dominici gregis w 1996 roku podnoszono tę rzekomą nowość jako fakt godny uwagi. Pojawiły się (już wtedy) sugestie, iż może mieć to związek ze stanem zdrowia i wiekiem Jana Pawła II. Zob. G. Marchesi, Le nuove norme per l'elezione del Papa, „La Civiltà Cattolica”, R. 147, 1996, s. 283.

9 AAS, R. 67, 1975, s. 609-645. Tłumaczenie polskie: Posoborowe prawodawstwo kościelne, red. E. Sztafrowski, t. 8, z. 1, Warszawa 1977, s. 7-76.

io Por. UDG 3, 34, 37 oraz te same artykuły w konstytucji Romano Pontifici eligendo.

II Zob. P. G. Carron, La rinuncia all'ufficio ecclesiastico nella storia del diritto canonico dalla età apostolica alla Riforma cattolica, Milano 1946, passim; P. Granfield, Papal resignation, „The Jurist”, R. 38, 1978, s. 118-123; [b.a.] Papieże, którzy zrzekli się urzędu, „L'Osservatore Romano" (wyd. pol.), R. 34, 2013, nr 3-4, s. 54-56. 
tak iż niektóre rezygnacje uchodzą jedynie za legendarne ${ }^{12}$, inne znów były w różnym stopniu wymuszone, czy to przez władzę świecką, czy przez sobór powszechny, czy wreszcie przez zamieszki ${ }^{13}$, tak iż nie spełniają kryterium dobrowolności i należy je traktować raczej jako złożenie z urzędu, bądź też chodziło o antypapieży, a zatem osoby niebędące legalnymi następcami św. Piotra. Praktycznie jedyną niekwestionowaną dymisją papieską jest rezygnacja św. Celestyna V, który wybrany na następcę św. Piotra w 1294 roku, po kilku miesiącach sprawowania papieskiego urzędu zrzekł się biskupstwa rzymskiego wobec zgromadzonych kardynałów.

Abdykacja Celestyna V ma istotne znaczenie w historii tej instytucji kanonicznej nie tylko $\mathrm{z}$ powodu aktu rezygnacji samego w sobie, ale przede wszystkim z tego powodu, iż stała się ona przyczynkiem do wprowadzenia do kanonicznego porządku prawnego przepisu o możliwości złożenia rezygnacji przez Biskupa Rzymskiego. Do końca XIII wieku nie było to bowiem jednoznaczne. Niektórzy średniowieczni kanoniści nie dopuszczali takiej możliwości, argumentując, iż papież nie może zrezygnować z pełnionej funkcji, jako że nie ma wyższej od niego instancji, która mogłaby taką rezygnację przyjąć: Sancta Sedes a nemine iudicatur. Dowodzono ponadto, że papież jest nierozłącznie związany ze Stolicą św. Piotra na podobieństwo węzła małżeńskiego, którego nikt, oprócz śmierci, nie może rozwiązać. Dlatego po złożeniu urzędu przez Celestyna niektórzy, pośród zaciekłych polemik doktrynalnych, podważali legalność wyboru jego następcy, Bonifacego VIII: skoro papież Celestyn nie mógł ważnie abdykować, wybór jego następcy jest nieważny - twierdzili ${ }^{14}$.

Sam Bonifacy VIII położył kres tym dyskusjom, wydając w 1299 roku dekretał De renuntiatione papae, potwierdzający, iż Biskup Rzymski może zrezygnować ze swego urzędu, a jego rezygnacja nie wymaga niczyjej zgody ${ }^{15}$.

I2 Jak np. św. Klemens Rzymski - hipotezę o jego rezygnacji wysuwał Epifaniusz z Salaminy: Klemens miał ustąpić na rzecz Linusa, a po jego śmierci znów objął biskupstwo rzymskie. Nie jest także potwierdzona rezygnacja papieża Marcelina (296-304).

I3 Np. papież Poncjan deportowany w 235 roku na Sardynię i skazany na pracę w kopalni, Sylweriusz usunięty z urzędu przez cesarzową Teodorę w 537 roku.

I4 Zob. P. Granfield, Papal resignation, dz. cyt., s. 123-128.

Is C. 1 , de renuntiatione, I, 7, in VIo: „Quoniam aliqui curiosi disceptantes de his quae non multum expediunt et plura sapere, quam oporteat, contra doctrinam Apostoli, temere appetentes, in dubitationem sollicitam, an Romanus Pontifex, maxime quum 
Dekretał ten wszedł w skład zbioru Bonifacego VIII Liber Sextus, stając się po upływie ponad sześciuset lat jedynym źródłem kan. 221 Kodeksu prawa kanonicznego z 1917 roku przywołanym w edycji kodeksu cum fontibus. Odpowiednikiem tego przepisu w obecnie obowiązującym Kodeksie prawa kanonicznego z 1983 roku jest kan. 332 \$2, który brzmi: „Gdyby się zdarzyło, że Biskup Rzymski zrzekłby się swego urzędu, to do ważności wymaga się, by zrzeczenie zostało dokonane w sposób wolny i było odpowiednio oznajmione; nie wymaga zaś niczyjego przyjęcia”.

\section{Przyczyny rezygnacji}

Kanon $332 \$ 2$ KPK, nawiązując do średniowiecznych polemik, wskazuje po pierwsze, że papież może zrezygnować ze swej funkcji. Analogicznie do dobrowolnego przyjęcia wyboru dokonanego przez kardynałów-elektorów na konklawe - a akceptacja wyboru przez elekta rodzi skutki bezwarunkowo i natychmiast ${ }^{16}$ - papież może wycofać daną wcześniej przez siebie zgodę na pełnienie Piotrowej posługi ${ }^{17}$. Ustąpienie z urzędu Biskupa Rzymu jest w założeniu decyzją nadzwyczajną. Wskazuje na to brzmienie kan. 332

se insufficientem agnoscit ad regendam universalem ecclesiam et summi pontifcis onera supportando, renunciare valeat papatui eiusque oneri et honori, deducere minus provide videbantur: Coelestinus Papa quintus, praedecessor noster, dum eiusdem ecclesiae regimini praesidebat, volens super hoc haesitationis cujuslibet materiam amputare, deliberatione habita cum suis fratribus ecclesiae Romanae cardinalibus, de quorum numero tunc eramus, de nostro et ipsorum concordi consilio et assensu, auctoritate apostolica statuit et decrevit, Romanum Pontificem posse libere resignare. Nos igitur, ne statutum hujusmodi per temporis cursum oblivioni dari, aut dubitationem eandem in recidivam disceptationem ulterius deduci contingat, ipsum inter constitutiones alias ad perpetuam rei memoriam de fratrum nostrorum consilio duximus redigendum".

I6 Zob. UDG 87-88. Kwestią dyskutowaną przez autorów jest moment otrzymania władzy przez elekta, który nie posiada sakry biskupiej. Postanowienie UDG 88 nie przesądza o tym, czy wybrany na Biskupa Rzymu elekt bez święceń biskupich otrzymuje pełnię władzy papieskiej z chwilą przyjęcia wyboru, czy też dopiero wraz z przyjęciem święceń episkopatu. Zob. G. Ghirlanda, Accettazione della legittima elezione e consacrazione episcopale del Romano Pontefice secondo la Cost. Ap. "Universi Dominici gregis” di Giovanni Paolo II, „Periodica de re canonica”, R. 86, 1997, s. 615-656.

${ }^{17}$ „Quare sicut R. Pontifex per acceptationem liberam electionis primatum iurisdictionis actu consecutus est, ita per liberam et publice declaratam dimissionem dignitatis suae iurisdictionem papalem amittit" (F. X. Wernz, P. Vidal, Ius canonicum..., dz. cyt., s. 436). 
$\$ 2$, który - rozszerzając wymowę dekretału Bonifacego VIII - nie stanowi tylko o prawie papieża do zrzeczenia się swego urzędu („Romanum Pontificem posse libere resignare”), ale podkreśla jednocześnie absolutną wyjątkowość takiej decyzji (,gdyby się zda r zyło, że Biskup Rzymski zrzekłby się swego urzędu...”).

Zważywszy na najwyższą rangę urzędu Biskupa Rzymu w Kościele, przyczyna rezygnacji z tej funkcji, zdaniem autorów, musi być do niej proporcjonalna, czyli bardzo poważna ${ }^{18}$, choć pozostawiona jest ona swobodnej ocenie i sumieniu samego papieża, który podejmując ów akt, nie jest uzależniony od niczyjej woli lub sugestii. Do ważności rezygnacji nie wymaga się żadnej konkretnej przyczyny. Autorzy wskazują jednak, iż byłaby ona usprawiedliwiona tylko pożytkiem lub koniecznością Kościoła powszechnego, względnie dobrem duchowym samego papieża. Pośród przyczyn, które mogłyby być brane pod uwagę, w piśmiennictwie wskazywano ${ }^{19}$ : nieprawidłowość kanoniczną odnoszącą się do osoby papieża, publiczną wiedzę o występku, jakiego by się dopuścił papież i wiążące się z tym zgorszenie, wrogość ze strony ludu, która nie mogłaby być zażegnana lub chociażby tolerowana, pragnienie zapobieżenia lub zażegnania wielkiego zgorszenia, utratę zdolności do sprawowania pasterskich rządów nad Kościołem wskutek demencji starczej, ciężkiej choroby, zwłaszcza poważnych niedomagań natury psychicznej, podeszłego wieku, a także pragnienie prowadzenia życia zakonnego lub pustelniczego. Należy pamiętać, że gdy mowa o podeszłym wieku, nie jest on w żaden ukonkretniony sposób nawet zasugerowany, skoro papieża nie obowiązuje zaproszenie do złożenia rezygnacji z urzędu po ukończeniu 75. roku życia, jak stanowi kan. $401 \$ 1 \mathrm{KPK}$ w odniesieniu do wszystkich biskupów diecezjalnych.

Warto przytoczyć motywy rezygnacji, jakie przedstawił Benedykt XVI w oświadczeniu złożonym podczas Konsystorza Publicznego 11 lutego 2013 roku: „Rozważywszy po wielokroć rzecz w sumieniu przed Bogiem, zyskałem pewność, że z powodu podeszłego wieku moje siły nie są już wystarczające, aby

I8 Kan. 187 KPK dla rezygnacji z urzędu kościelnego wymaga przyczyny „słusznej” (iusta causa). W kan. $189 \$ 2$ mówi się ponadto, by przyczyna ta była „proporcjonalna”. W przypadku rezygnacji z posługi Następcy św. Piotra wskazuje się, że jest ona usprawiedliwiona powodem najwyższej wagi - causa gravissima. Zob. D. Salvatori, La cessazione dell'ufficio del Romano Pontefice, „Quaderni di Diritto Ecclesiale”, R. 22, 2009, s. 281.

is Zob. P. Granfield, Papal resignation, dz. cyt., s. 127. 
w sposób należyty sprawować posługę Piotrową. Jestem w pełni świadom, że ta posługa, w jej duchowej istocie powinna być spełniana nie tylko przez czyny i słowa, ale w nie mniejszym stopniu także przez cierpienie i modlitwę. Tym niemniej, aby kierowaćłodzią św. Piotra i głosić Ewangelię w dzisiejszym świecie, podlegającym szybkim przemianom i wzburzanym przez kwestie o wielkim znaczeniu dla życia wiary, niezbędna jest siła zarówno ciała, jak i ducha, która w ostatnich miesiącach osłabła we mnie na tyle, że muszę uznać moją niezdolność do dobrego wykonywania powierzonej mi posługi”"20.

Rezygnacja papieża bez poważnej przyczyny byłaby niegodziwa i naganna moralnie, ale mimo to ważna ${ }^{21}$, bowiem do ważności wymaga się jedynie nieprzymuszonej woli ustąpienia z urzędu, należycie oznajmionej. Podobnie nie byłaby dotknięta nieważnością rezygnacja Biskupa Rzymu, który nie upubliczniłby wyraźnej przyczyny, dla której podjął decyzję o ustąpieniu.

\section{Wolność decyzji}

Wolność decyzji jest jednym z dwóch wymogów ad validitatem, jakie w kan. $332 \$ 2$ KPK pojawiają się w odniesieniu do rezygnacji papieża z urzędu: „do ważności wymaga się, by zrzeczenie zostało dokonane w sposób wolny".

Mimo iż przepisy Kodeksu prawa kanonicznego regulujące ustąpienie z urzędu nie mają zastosowania do papieża, komentatorzy ${ }^{22}$, mówiąc o koniecznej wolności takiej decyzji, odsyłają do kan. $187 \mathrm{KPK}$, który wymaga poczytalności ${ }^{23}$ składającego urząd, a także do kan. 188, który stanowi, iż rezygnacja

\footnotetext{
20 „L'Osservatore Romano” (wyd. pol.), R. 34, 2013, nr 3-4, s. 4.

${ }_{21}$ Zob. F. X. Wernz, P. Vidal, Ius canonicum..., dz. cyt., s. 436; P. Granfield, Papal resignation, dz. cyt., s. 129.

22 Zob. J. Manzanares, Il Romano Pontefice..., dz. cyt., s. 59; E. Molano, Komentarz do kan. 332, [w:] Comentario exegético..., dz. cyt., s. 577; D. Salvatori, La cessazione..., dz. cyt., s. 280-281.

${ }_{23}$ W kanonie używa się tradycyjnego zwrotu sui compos. Można mieć pewne zastrzeżenia do tłumaczenia tego wyrażenia na „poczytalny” (o poczytalności mowa raczej w kontekście odpowiedzialności karnej). Tymczasem znaczenie compos sui jest bogatsze: „świadom siebie samego”, „władający (rozumem, ciałem)”. Zob. A. Jougan, Stownik kościelny tacińsko-polski, Warszawa 1992, s. 130; J. Sondel, Stownik tacinsko-polski dla prawników i historyków, Kraków 1997, s. 184. Chodzi zatem o tego, który „jest panem samego siebie”,
} 
dokonana pod wpływem ciężkiej i niesprawiedliwej bojaźni, podstępu, istotnego błędu lub symonii jest nieważna. Bojaźń rozumiana jest jako reakcja na groźbę pochodzącą z przyczyny zewnętrznej (a więc nie może chodzić np. o wyrzuty sumienia) i ludzkiej (nie zaś od sił przyrody - mowa jest o tzw. przyczynie wolnej), tak iż jedynym jawiącym się wyjściem z sytuacji zagrożenia byłoby ustąpienie z urzędu Biskupa Rzymskiego (w przypadku papieża nie można jednak ograniczać się jedynie do bojaźni wywołanej niesprawiedliwie). Błąd istotny oznaczałby fałszywy sąd papieża na temat jakiegoś istotnego elementu rezygnacji. Nieważność powodowałby także podstęp, czyli rozmyślne działanie lub zaniechanie zmierzające, poprzez oszukańczą manipulację, do wprowadzenia papieża w błąd, a tym samym nakłonienia go do ustąpienia (np. poprzez sfałszowanie opinii lekarskiej, aby w ten sposób skłonić go do złożenia urzędu). Symonia to odejście z urzędu w zamian za korzyści, najczęściej materialne ${ }^{24}$. Do wymienionych przesłanek nieważności rezygnacji należałoby dodać także przymus fizyczny - sprawia on nieważność czynności prawnych w ogóle ${ }^{25}$. Niektórzy kanoniści włączają do nich również chorobę psychiczną papieża, inni - jak wspomniano wyżej - wolą uznawać ją za samoistną przyczynę utraty przezeń urzędu Biskupa Rzymu, względnie traktują ją jako okoliczność powodującą przeszkodę w działaniu Stolicy Świętej.

Podejmując decyzję o ustąpieniu, papież w żaden sposób nie jest związany postanowieniami, przykładem czy sugestiami swych poprzedników ${ }^{26}$. Jako dominus canonum nie ma nawet obowiązku przestrzegania prawa, które nakazywałoby mu odejście z urzędu, gdyby taki przepis został wydany przez któregoś z papieży. Rezygnacja winna być absolutnie dobrowolnym, osobistym aktem Biskupa Rzymu, wyłącznie przez niego ocenianym i podejmowanym samodzielnie, co oczywiście nie wyklucza możliwości konsultacji z osobami, którym sam zechciałby przedstawić swój zamysł.

włada sobą samym, posiada zdolność rozumienia i chcenia, a podjętą przez siebie decyzję uznaje za własną.

${ }^{24}$ Symonia jest nie tylko przyczyną nieważności rezygnacji z urzędu, ale także powierzenia każdego urzędu kościelnego (zob. kan. 149 \$3). Nie powoduje jednak nieważności wyboru papieża (zob. UDG 78), tak by nie dawać powodów do podważania wyboru Biskupa Rzymskiego, aczkolwiek winni ewentualnego przestępstwa symonii podczas konklawe zaciągają karę ekskomuniki latae sententiae.

${ }_{25}$ Zob. kan. $125 \$ 1 \mathrm{KPK}$.

26 Zob. G. Bier, Komentarz do kan. 332, nr 5 i 10. 
Wszczynanie post factum dyskusji nad ewentualnymi czynnikami, które mogły naruszyć dobrowolność papieskiej decyzji o rezygnacji byłoby dla Kościoła ogromnie niebezpieczne, zważywszy, iż po złożeniu rezygnacji papież całkowicie traci najwyższą władzę w Kościele, Stolica Rzymska wakuje, a Kolegium Kardynałów elektorów przystępuje do wyboru nowego papieża. Kwestionowanie wolności decyzji papieża, który zrezygnował z posługi następcy św. Piotra, mogłoby otworzyć wysoce szkodliwe polemiki i dyskusje, włącznie z podważaniem legalności wyboru nowego Biskupa Rzymu. Dlatego niezwykle ważne jest, by w akcie rezygnacji papieskiej jej dobrowolność była odpowiednio zaznaczona, tak by nie dawać najmniejszych podstaw do podawania jej w wątpliwość.

Benedykt XVI, składając rezygnację, w słowach skierowanych do kardynałów wyraźnie podkreślił, że swą decyzję podjął „w pełni świadom powagi tego aktu, z pełną wolnością" ${ }^{27}$. Podczas ostatniej audiencji generalnej 27 lutego 2013 roku ponownie zaakcentował, iż krok ten uczynił „z całą świadomością jego znaczenia"28, po usilnej modlitwie, podczas której prosił Boga o światło potrzebne do podjęcia najbardziej słusznej decyzji dla dobra Kościoła.

\section{Ogłoszenie rezygnacji}

Stosowne oznajmienie rezygnacji jest drugim warunkiem, jaki kan. 332 $\$ 2$ stawia do ważności tego aktu. Ustawodawca używa sformułowania rite manifestetur, co tłumaczy się na język polski, iż rezygnacja winna być oznajmiona „odpowiednio”.

Inne tłumaczenia łacińskiego przysłówka rite, to „słusznie”, „należycie”, we właściwy sposób”, ale także „według formy przepisanej prawem”, „prawnie”, „formalnie”29. Nie wydaje się jednak - jak twierdzą niektórzy autorzy $^{30}$ - by przepis wspomnianego kanonu winien być uzupełniony przez

27 „L'Osservatore Romano” (wyd. pol.), R. 34, 2013, nr 3-4, s. 4.

28 Tamże, s. 7.

29 Zob. A. Jougan, Stownik kościelny..., dz. cyt., s. 592; J. Sondel, Stownik tacińsko-polski..., dz. cyt., s. 847.

3o Zob. D. J. Andrés Gutiérrez, Komentarz do kan. 332, [w:] Código de Derecho Canónico. Edición bilingüe, fuentes y comentarios de todos los cánones, red. A. Benlloch Poveda, Valencia 1993, s. 177; A. P. Abate, Komentarz do kan. 332, [w:] Commento al Codice di Diritto Canonico, red. P. V. Pinto, Città del Vaticano 2001, s. 298. 
specjalną ustawę, która szczegółowo regulowałaby formę złożenia rezygnacji przez papieża. Inaczej niż stanowi kan. $189 \$ 1 \mathrm{KPK}$ dla wszystkich urzędów kościelnych ${ }^{31}$, w odniesieniu do Biskupa Rzymskiego nie jest przewidziana żadna konkretna forma rezygnacji, a w szczególności nie wymaga się formy pisemnej czy obecności prawnie ustanowionych świadków tej czynności. Do ważności rezygnacji wystarcza, by była ona ogłoszona „odpowiednio”, natomiast to sam papież określa szczegółową formę oznajmienia swojej decyzji. Narzucanie konkretnej formy stanowiłoby swego rodzaju ograniczenie papieża, tymczasem ustąpienie z urzędu jest osobistym aktem, jaki podejmuje $^{32}$. Może uczynić to na piśmie lub ustnie ${ }^{33}$, może posłużyć się środkami społecznego przekazu lub ogłosić wiadomość o zrzeczeniu się urzędu bez pośrednictwa mediów, może uczynić to wobec Kolegium Kardynalskiego - tak właśnie uczynili to Celestyn V i Benedykt XVI - lub w obecności dowolnie wybranych przez siebie osób. Niezwykle ważne jest natomiast, by rezygnacja papieża była oznajmiona w sposób pewny.

Dla pewności prawnej i stanowczego wykluczenia wszystkich wątpliwości - nie trzeba przekonywać, jak ogromne trudności i niebezpieczeństwo dla jedności Kościoła powstałyby, gdyby rezygnacja papieża i sposób jej oznajmienia były niepewne - ogłoszenie ustąpienia z urzędu przez Biskupa Rzymskiego winno być dokonane w sposób bezsporny, jednoznaczny, tak by nie pozostawiało jakiegokolwiek pola do podejrzeń i nie rodziło niepewności ${ }^{34}$. Z tej samej racji najbardziej wskazane jest, by papież o swej decyzji ustąpienia z urzędu powiadomił osobiście, bez uciekania się do pośrednika ${ }^{35}$.

Powszechny charakter posługi następcy św. Piotra domaga się, by ewentualne ustąpienie papieża z pełnienia tej funkcji miało wymiar publiczny

${ }_{31}$ W kan. 189 do ważności rezygnacji wymaga się, by została ona złożona na piśmie lub ustnie, w obecności dwóch świadków, wobec tego, kto powierza dany urząd.

32 Zob. D. Salvatori, La cessazione..., dz. cyt., s. 280.

33 Rezygnacja Benedykta XVI została oznajmiona w formie ustnego oświadczenia, ale był przygotowany stosowny dokument, który papież odczytał podczas Konsystorza Publicznego 11 lutego 2013 roku. Dokument nosi datę 10 lutego 2013 roku. Zob. „L'Osservatore Romano” (wyd. pol.), R. 34, 2013, nr 3-4, s. 4.

34 Rezygnacja wątpliwa nie byłaby prawnie skuteczna. Zob. D. Salvatori, La cessazione..., dz. cyt., s. 278.

35 Zob. tamże, s. 280. Natomiast rezygnacja z innych urzędów kościelnych może być złożona przez pełnomocnika. 
i dotarło w sposób oczywisty i niewątpliwy do całego Kościoła ${ }^{36}$. Tym bardziej, że nie jest przewidziany żaden podmiot, wobec którego papież winien oficjalnie złożyć rezygnację i który powinien ją odebrać (nie w sensie zaakceptowania jej lub odrzucenia, ale zwykłego przyjęcia do wiadomości) i potwierdzić, zapoczątkowując tym samym okres wakatu Stolicy Apostolskiej $^{37}$. Wydaje się stosowne, by wiadomość o ustąpieniu z urzędu Biskupa Rzymskiego dotarła w pierwszej kolejności do grona kardynałów, którzy przejmują zarządzanie Kościołem w czasie sede vacante i mają przystąpić do wyboru kolejnego papieża.

\section{Konstytutywny charakter rezygnacji}

Rezygnacja papieża z urzędu jest klasycznym przykładem rezygnacji konstytutywnej, czyli takiej, która swój skutek osiąga jedynie w następstwie oznajmienia decyzji o ustąpieniu. Nie wymaga się natomiast, by była ona przez kogokolwiek przyjmowana (w sensie jej akceptacji lub odrzucenia). Przyczyną, dla której kanoniczny porządek prawny wyklucza, by ktokolwiek przyjmował (potwierdzał) decyzję Biskupa Rzymu o odejściu z pełnionej przez siebie funkcji, jest najwyższa ranga tego urzędu w Kościele: ponad papieżem nie ma wyższego organu władzy, który mógłby przyjąć jego rezygnację. Jest to także konsekwencja zasady: Romanus Pontifex a nemine iudicatur $^{38}$.

Brak wymagania przyjęcia rezygnacji jest w prawie kanonicznym typowy dla urzędów powierzanych w drodze wyboru konstytutywnego ${ }^{39}$. Nade wszystko nie są upoważnieni do przyjmowania dymisji papieża kardynałowie elektorzy (mimo iż to właśnie oni go wybrali) - o czym wyraźnie

36 Zob. tamże, s. 279.

37 W przypadku rezygnacji Benedykta XVI sam papież w oświadczeniu złożonym podczas Konsystorza Publicznego precyzyjnie określił moment, w którym rozpocznie się czas sede vacante - „od 28 lutego 2013 roku, od godziny 20.00”.

${ }_{38}$ Zob. kan. $1404 \mathrm{KPK}$.

39 Zob. kan. 178, $189 \$ 3$ i $430 \$ 2$ KPK. Kodeks prawa kanonicznego stanowi wyraźnie, iż nie wymaga zatwierdzenia, oprócz wyboru papieża, wybór administratora diecezji. Nie jest wykluczony jednak taki sposób wyboru na inne urzędy, które nie są regulowane w kodeksie. Zob. szerzej G. Dzierżon, Powierzenie urzędu kościelnego poprzez wybór. Komentarz do regulacji zawartych w Księdze I Kodeksu Prawa Kanonicznego, Kraków 2012, s. 123-124. 
przypominał kan. 221 Kodeksu prawa kanonicznego z 1917 roku - ani sobór powszechny.

Konsekwencją konstytutywnego charakteru rezygnacji papieskiej jest jej nieodwołalność. Skoro rezygnacja osiagga swój skutek bez potrzeby niczyjej akceptacji, z chwilą wejścia w życie decyzji o złożeniu urzędu, papież traci całą władzę papieską i nie może już cofnąć swej decyzji, jako że nie ma wówczas żadnego tytułu prawnego, by rezygnację odwołać. Nie może odzyskać władzy przysługującej mu jako Biskupowi Rzymskiemu, którą utracił wraz z wejściem w życie swej własnej decyzji o ustąpieniu. Stolica Apostolska staje się bowiem ipso facto wakująca, a jedynym sposobem jej obsadzenia jest wybór nowego papieża przez kardynałów elektorów zgromadzonych na konklawe.

$Z$ tej racji nie mają wiążącej mocy prawnej ewentualne warunki dołączone przez papieża do zrzeczenia się z urzędu - np. wskazanie swego następcy lub pozostawienie sobie pewnych prerogatyw ${ }^{40}$. $Z$ tego samego powodu pozbawione mocy prawnej byłyby jakiekolwiek zarządzenia, dyspozycje, polecenia czy zwykłe życzenia ustępującego papieża skierowane do przyszłego konklawe lub swego następcy. Czym innym są natomiast ustawy wydane i promulgowane przez Biskupa Rzymu jeszcze w czasie pełnienia przezeń swego urzędu - winny być one zachowywane tak jak pozostałe ustawy kościelne, choć nowy papież mógłby je zmodyfikować lub znieść całkowicie ${ }^{41}$.

Odwołanie papieskiej decyzji o ustąpieniu z urzędu nie jest możliwe, gdy już osiągnie ona swój skutek. Natomiast może być ona odwołana przez

40 Kanoniczny porządek prawny dopuszcza natomiast rezygnację warunkową z urzędu proboszcza. Zob. kan. 1743 KPK. Wymaga się jednak, by taki warunek był możliwy do spełnienia i został przyjęty przez biskupa. Do czasu spełnienia się warunku rezygnujący proboszcz mógłby odwołać swe zrzeczenie się z urzędu. Zob. E. Labandeira, Komentarz do kan. 1743, [w:] Kodeks Prawa Kanonicznego. Komentarz, dz. cyt., s. 1310.

${ }^{4}$ Przykładem takiej ustawy jest motu proprio Benedykta XVI Normas nonnullas z 22 lutego 2013 roku, w którym papież, już po ogłoszeniu swej rezygnacji, ale jeszcze przed wejściem jej w życie, dokonał pewnych zmian w prawie regulującym wybór nowego papieża. Dokument ten został promulgowany w odmienny niż zazwyczaj sposób (zob. kan. $8 \$ 1 \mathrm{KPK})$, nie poprzez ogłoszenie w urzędowym organie „Acta Apostolicae Sedis”, ale w dzienniku watykańskim „L'Osservatore Romano” z 25-26 lutego 2013 roku (s. 7). Ustawa weszła w życie w dniu ogłoszenia, bez normalnie przepisanej trzymiesięcznej vacatio legis, ale zgodnie z kan. $8 \$ 1 \mathrm{KPK}$. Taki sposób postępowania był możliwy dzięki rozdzieleniu w czasie oznajmienia decyzji o ustąpieniu z urzędu przez papieża od jej wejścia w życie. 
samego papieża, zanim weszła w życie ${ }^{42}$. W przypadku rezygnacji Benedykta XVI jego zrzeczenie się urzędu, choć oznajmione 11 lutego 2013 roku, weszło w życie kilkanaście dni później, bo 28 lutego 2013 roku o godz. 20.00. Do tego czasu Benedykt XVI sprawował pełną władzę papieską ${ }^{43}$ i mógłby swobodnie odwołać decyzję o swym zrzeczeniu się z urzędu.

W związku z powyższym należy wspomnieć o dyskusyjnej kwestii rezygnacji papieża w formule nunc pro tunc, czyli ogłoszeniu przez Biskupa Rzymskiego woli ustąpienia z urzędu, jeśli zajdą odpowiednie okoliczności, weryfikację których papież powierza innemu niż on sam podmiotowi - np. wskazanym osobom lub całemu Kolegium Kardynalskiemu. Sporządzenie pisma z rezygnacją w takiej formie przypisuje się Janowi Pawłowi II, który w nieogłoszonym za jego życia rękopisie z 15 lutego 1989 roku miał oświadczyć, że w przypadku nieuleczalnej choroby, która uniemożliwiłaby mu sprawowanie w dostateczny sposób posługi apostolskiej, albo w przypadku innej ciężkiej lub długotrwałej trudności, zrzeka się urzędu Biskupa Rzymu, a przyjęcie i wprowadzenie w życie tej decyzji powierza Dziekanowi Kolegium Kardynalskiego wraz z kardynałami stojącymi na czele dykasterii Kurii Rzymskiej oraz Wikariuszem Rzymu, lub - gdyby ich zwołanie było niemożliwe - kardynałom stojącym na czele poszczególnych stopni Kolegium $^{44}$.

42 Dotyczy to również rezygnacji z jakiegokolwiek innego urzędu kościelnego. Zob. kan. $189 \$ 4 \mathrm{KPK}$.

43 Wymowne były słowa Ojca Świętego wygłoszone w Castel Gandolfo w dniu odejścia z urzędu: „Jak wiecie, ten dzień jest dla mnie inny od poprzednich; nie jestem już Papieżem Kościoła katolickiego - będę nim jeszcze do ósmej wieczorem, a później już nie” („L'Osservatore Romano" (wyd. pol.), R. 34, 2013, nr 3-4, s. 9).

44 „Idąc za przykładem Ojca Świętego Pawła VI (zob. tekst z 2 II 1965) oświadczam, że: - w przypadku choroby uznanej za przypuszczalnie nieuleczalną, długotrwałej i która uniemożliwi mi sprawowanie w dostateczny sposób mojej posługi apostolskiej, - lub też w przypadku, gdyby inna ciężka lub długotrwała trudność była w tym również możliwą przeszkodą, - rezygnuję z mojego świętego i kanonicznego urzędu, zarówno jako biskupa Rzymu, jak i Głowy Świętego Kościoła katolickiego, składając na ręce Księdza Kardynała Dziekana Świętego Kolegium Kardynalskiego, wraz z przynajmniej Księżmi Kardynałami stojącymi na czele Dykasterii Kurii Rzymskiej i Kardynałowi Wikariuszowi Rzymu (pod warunkiem, że można ich normalnie powołać, a w przeciwnym razie Kardynałom zwierzchnikom poszczególnych stopni Świętego Kolegium) władzę przyjęcia i wprowadzenia w życie (sic.) tej mojej dymisji - w imię Trójcy Przenajświętszej. Romae, 15 II 1989. Ioannes Paulus PP II" (S. Oder, S. Gaeta, Dlatego święty. Prawdziwy Jan Pawet II, o którym 
Taki sposób zrzeczenia się z urzędu, choć niewątpliwie stanowi pewne zabezpieczenie możliwości sprawowania prymatu i wolności Kościoła na wypadek poważnej choroby papieża lub innej ważkiej przeszkody w sprawowaniu przezeń funkcji Biskupa Rzymu (np. uwięzienia), w których to okolicznościach złożenie przezeń rezygnacji byłoby niemożliwe z uwagi na brak kontaktu ze światem ${ }^{45}$, niesie ze sobą niemałe wątpliwości i poważne znaki zapytania. Po pierwsze, w takich przypadkach bardzo delikatnie jawi się rozgraniczenie między zwykłym stwierdzeniem faktów, od zaistnienia których papież uzależnił swą rezygnację, a istotną decyzją podejmowaną przez kogoś innego niż sam Biskup Rzymski. W rezultacie papieska rezygnacja mogłaby w pewnych okolicznościach przybrać formę ukrytego odwołania go z urzędu. Inną pojawiającą się poważną komplikacją byłby brak możliwości odwołania rezygnacji przez papieża, do czego zawsze ma prawo przed wejściem w życie skutków prawnych swego ustąpienia, a co w tym przypadku uniemożliwiałyby stan zdrowia psychicznego lub fizyczne pozbawienie wolności, jeśli w tych warunkach papież nie mógłby swobodnie podejmować decyzji. Podobne zastrzeżenia można by podnosić, gdyby papież uzależnił swą dymisję od osiągnięcia określonego wieku, a wcześniej zapadł na chorobę psychiczną lub znalazł się w innego rodzaju stanie, który uniemożliwiłby mu wycofanie się z wcześniejszej decyzji o rezygnacji.

\section{Status emerytowanego papieża}

Po ogłoszeniu zrzeczenia się z urzędu przez Benedykta XVI zadawano wiele pytań na temat jego pozycji w Kościele po ustąpieniu, a zwłaszcza po tym, gdy już zostanie wybrany jego następca na Stolicy św. Piotra. Szereg kwestii, które były przedmiotem tych szczególnie intensywnych dociekań - jak np. strój, miejsce zamieszkania, używanie dotychczasowego imienia - ma mniejsze znaczenie, gdy chodzi o status kanoniczny „emerytowanego papieża”, ale

opowiada postulator procesu beatyfikacyjnego, Kraków 2012, s. 146-147. Poprawki tłumaczenia od autora).

45 Pius VII w 1804 roku, gdy został nakłoniony do podróży do Paryża na koronację Napoleona, podpisał dokument, w którym zrzekał się urzędu w razie uwięzienia we Francji. Zob. Z. Zieliński, Papiestwo i papieże dwóch ostatnich wieków, t. 1, Poznań 1986, s. 8182. Podobnie o Piusie XII podaje się, że w czasie II wojny światowej miał podpisać swoją rezygnację na wypadek aresztowania go przez Niemców. 
wśród rozważanych zagadnień były i takie, które godne są zainteresowania kanonisty.

Benedykt XVI po ogłoszeniu rezygnacji uznał, iż jego tytułami, którymi będzie oficjalnie się posługiwał, będą „emerytowany biskup Rzymu” lub „emerytowany papież”. Tytuły te są analogiczne do tytułu, jaki noszą emerytowani biskupi diecezjalni ${ }^{46}$. Aby nie wywoływać wrażenia, że istnieje „dwóch papieży” roztropną rzeczą będzie powstrzymanie się emerytowanego biskupa Rzymu od publicznych wystąpień i wycofanie się z publicznych funkcji, co zapowiedział Benedykt XVI po ogłoszeniu swej rezygnacji ${ }^{47}$, deklarując jednocześnie pełne posłuszeństwo swemu następcy ${ }^{48}$. Prowadząc życie modlitwy, emerytowany papież w sposób szczególny podejmuje współodpowiedzialność za Kościół powszechny ${ }^{49}$ - upodabnia się w tym do każdego emerytowanego biskupa, który jako członek Kolegium Biskupów wezwany jest do budowania Kościoła w komunii i współodpowiedzialności razem z wszystkimi innymi biskupami i pozostaje uczestnikiem zatroskania o Kościół powszechny ${ }^{50}$.

Kodeks prawa kanonicznego, ani żaden inny dokument kościelny, nie zawiera normy regulującej kwestię przynależności emerytowanego papieża do Kolegium Kardynalskiego. Kwestia ta nie została oficjalnie rozstrzygnięta przy okazji rezygnacji Benedykta XVI. Jeśli przyjąć, że powołany na stolicę

${ }^{46}$ Zob. kan. 185 i 402 KPK. W sensie prawnym przechodzący na emeryturę biskup diecezjalny staje się biskupem tytularnym (zob. kan. 376). Nie przyznaje się mu jednak innej diecezji tytularnej.

47 „Nie wracam do życia prywatnego, do podróżowania, spotkań, przyjęć, wykładów itd. Nie porzucam krzyża, lecz w nowy sposób trwam przy ukrzyżowanym Panu. Nie mam już władzy rządzenia w Kościele, lecz w posłudze modlitwy zostaję, że tak powiem, w zagrodzie św. Piotra” (Benedykt XVI, Audiencja generalna w dniu 27 lutego 2013 r., „L'Osservatore Romano” (wyd. pol.), R. 34, 2013, nr 3-4, s. 7).

${ }^{48}$ „Wśród was, w Kolegium Kardynalskim, jest także przyszły papież, któremu już dziś przyrzekam bezwarunkowy szacunek i posłuszeństwo" (Benedykt XVI, Spotkanie z Kolegium Kardynatów, 28 II 2013, „L'Osservatore Romano” (wyd. pol.), R. 34, 2013, nr 3-4, s. 8).

49 „Chciałbym dalej moim sercem, moją miłością, moją modlitwą, moją refleksją, wszystkimi duchowymi siłami działać dla wspólnego dobra i dla dobra Kościoła oraz ludzkości” (Benedykt XVI, Do mieszkańców Castel Gandolfo, 28 II 2013, „L'Osservatore Romano" [wyd. pol.], R. 34, 2013, nr 3-4, s. 9).

so Zob. Kongregacja ds. Biskupów, Il vescovo emerito, Libreria Editrice Vaticana 2008, s. $15-18$. 
rzymską spośród kardynałów papież po wyborze i późniejszym ustąpieniu nie traci godności kardynalskiej - taka odpowiedź wydawałaby się właściwa właśnie dlatego, że kardynalat nie jest urzędem, ale najwyższą godnością w Kościele, tej zaś, w odróżnieniu od urzędu, nie traci się automatycznie mógłby brać udział w wyborze swego następcy ${ }^{51}$, o ile nie ukończył osiemdziesiątego roku życia. Niezależnie od tego emerytowany papież zachowuje bierne prawo wyborcze i - przynajmniej teoretycznie - mógłby zostać ponownie wybrany na Stolicę św. Piotra.

\section{Resignation of a Pope from His Office}

Summary

Resignation of the Pope Benedict XVI announced on 11ht Feb. 2013 was for many a huge astonishment, because in the history of the Church one can find not so many decisions like this one, and from the last one passed more than 600 years. For canonists the act is a novelty only de facto but not de iure, because the article about resignation of the pope from his office has existed in the canonical legal order since 1299.

The paper includes the interpretation of can. $332 \$ 2$ of the Code of Canon Law 1983 that regulates resignation of the Roman Pontiff from His Office. There are presented and analyzed historical circumstances of such norm, causes of such step, conditions required for validity of resignation (freedom of decision and proper announcement), constitutive character of such resignation and its irrevocability and the status of pope-emeritus in the Church.

Keywords: pope, Roman Pontiff, resignation, conclave, Catholic Church

sז Zob. G. Bier, Komentarz do kan. 332, dz. cyt., nr 10. 